\title{
リンゴ果実の各種糖類及びアスコルビン酸含量に 及ぼす環境要因の影響
}

\author{
近藤悟* \\ Effect of Environmental Conditions on the Contents of \\ Sugars and Ascorbic Acid in 'Senshu' Apple Fruit \\ Satoru KoNDO* \\ Akita Fruit Tree Research Station, Daigo, Hiraka, \\ Akita, 013-01
}

The effects of various environmental conditions, including exposure to light and fruit load, on the contents of sugars and ascorbic acid in 'Senshu' apple fruit, which is suitable to a high quality juice, were investigated.

(1) The contents of glucose, fructose and sucrose decreased by shading and bagging. The content of sucrose was greatly reduced by shading. The content of ascorbic acid was also reduced by bagging and shading. (2) Defoliation treatment reduced the total sugar content, especially sucrose. The ascorbic acid content was also reduced. Overcropping treatment reduced the fructose and sucrose contents greatly, and the ascorbic acid content was also reduced. However, the levels of the sugars and acid in better coloring fruits were higher than that of lower coloring. It was suggested that among the sugars sucrose was especially affected by the light conditions and fruit cropping, while ascorbic acid was related to photosynthate in addition to exposure to light.

(Received Jun. 17, 1992)

リンゴ果実の消費拡大のために，加工製品への期待が 高まっている，糖及び有機酸含量は果汁の品質を決定す る重要な要素であるが, 現在加工用として用いられてい る果実の品質は必ずしも満足すべきものではないと考え られる.リンゴ果実の糖含量 (Brix\%) 及び有機酸含 量と環境要因との関係に関する報告は多いが2)，各種 糖類（グルコース，フルクトース，ソルビトール）及び アスコルビン酸含量と光環境や着果量などとの相互関係 に関する報告は少ない，リンゴ果害のアスコルビン酸含 量については一般的に少ないとされているが，カンキッ 類に匹敵する程度含有している品種む報告されている また，リンゴ果実を果汁にした場合，還元型アスコルビ ン酸 (AsA) は酸化型アスコルビン酸 (DAsA) に急 速に変化するが, リンゴ果実の DAsA の安定性や耐熱 性は他の野菜・果実に比較して強く，加工品に好適であ

\section{るこどす報告されている.}

本報告では，前報 ${ }^{5)}$ の結果から果汁品質が良好であり， 㩁汁率など加工適応性に優れ，さらに栽培面積が比較的 多い'千秋’果実について，生育中の環境要因之各種糖 類及びアスコルビン酸との関係を検討したので報告する.

\section{実 験 方 法}

リンゴ ‘千秋’（MM. 106 及びマルバ台木, 13 年生） を用い，以下の環境条件の果実について糖の分別定量， アスコルビン酸の定量などを行った。

\section{1. 光環境しの関係}

寒冷紗（遮光率 $51 \%$ ，満開後 45 日から収穫時（满開 後 142 日）まで被覆）で主枝全体を覆った遮光処理区， 遮光率 72\%のハトロン紙で果実のみを覆った袋掛け処 理区（満開後 45 日被袋，収稜前 15 日除袋区及び無除袋 
区）を設けた，上記の処理は同一樹内で枝単位処理とし た.

\section{2. 摘葉処理，着果量亡の関係}

摘葉処理については技単位で行い，収橧前 15 日に果 そう葉の $80 \%$ ，新梢葉の $50 \%$ を摘葉した．なお，対照 区蝶摘葉とした。

着果量との関係については樹単位で処理し，過着果区 は葉果比 10, 対照区は葉果比 50 になるよう調整した。

\section{3. 果実傷害との関係}

果梗部に裂果障害のみられる果実を満開後 142 日（収 權適期)に収穫した。

各処理区の果実を収楼後，直ちに捽汁滤過し，糖の分 別定量を高速液体クロマトグラフ（日立 655 型，カラ $\measuredangle$ : GLC-611, 移動相: $10^{-4} \mathrm{~N} \mathrm{NaOH}$, 検出器: 示差 屆折計）を用いて行った。なお，本報告では定量したグ ルコース，フルクトース，スクロース，ソルビトールの 合計値を全糖含量として表示した，果実硬度はべネトロ メーター(Effegi 社：FT-327 型, プランジャー径 11 $\mathrm{mm}$ ), リンゴ酸含量は一定量の果汁を $0.1 \mathrm{~N}-\mathrm{NaOH}$ で中和滴定し，換算して求めた

果実中のアスコルビン酸に関しては，含有量の多い果

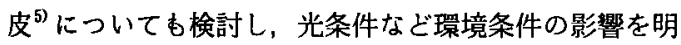
らかにしょうとした，定量は高速液体クロマトグラフ (日立 655 型, 力ラム：Lichrosorb $\mathrm{NH}_{2}$, 検出器： UV， $254 \mathrm{~nm}$ ）用い，MASUDA ら ${ }^{6)}$ 及び RICHARD and NAHRWOLD" の方法を若干変更して行った。

\section{実 験 結 果}

\section{1. 光環境との関係}

遮光処理区，袋掛け処理区とも対照区に比べ，グルコ 一ス，フルクトース，スクロース含量が減少した，特に 遮光処理区ではスクロース含量の低下が著しく，全糖含 量も大きく隇少した．また，糖酸比は袋掛け処理の無除 袋区，遮光処理区で大きく低下した，一方，同一果実内 の着色良好部位之着色不良部位では，糖，リンゴ酸含量 に有意差はみられなかった（Table 1). 果実中のアス コルビン酸含量に関しては Table 2 に示した，果肉で はアスコルビン酸の 52〜72\%，果皮では 72〜84\% が還 元型であった．果肉・果皮とも遮光処理及び袋掛け処理 区で低下したが，袋掛け処理区の収楼前 15 日除袋区で は無除袋区に比べ，若干增加した。 また同一果害内でも， 着色不良部位のアスコルビン酸含量は大きく低下した．

\section{2. 摘葉処理，着果量との関係}

摘葉処理を行った区では全糖含量が大きく減少し，ス
クロースの低下が著しかった (Table 3). Table 4 に 示すように，アスコルビン酸含量值は同程度に着色した 果実との比較では，果肉・果皮とも摘葉処理区で低下し た.

過着果区では対照区に比へ，グルコース，ソルビトー ル含量には差がみられなかったが，フルクトース，スク ロース含量が大きく隇少した。また過着果区の中でも， 着色の良好な果字では着色の劣る果実に比へ，フルクト ース，スクロース，全糖含量值が高加た。糖酸比にっ いても，着色の劣る果実では低下する傾向をみせた (Table 3).

アスコルビン酸含量は糖含量と同椂な傾向であり，過 着果区では低下したが，着色の良好な果実はどその值が 高かった (Table 4).

\section{3. 果実傷害との関係}

果梗部に裂果障害の認められた果実では，同程度の大 きさの対照果実と比較した場合，全糖含量には差か認め られなかったが，スクロース，リンゴ酸及びアスコルビ ン酸含量が減少した（Table 5，6).

Fig. 1 は果肉中の各種糖含量と還元型アスコルビン 酸含量との相関関保をみたものであるが，フルクトース， スクロース，全糖含量と $5 \%$ レベルで一次相関が認めら れた。

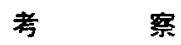

泉ら ${ }^{8)}$ はカンキッ果実について，樹冠内の着果位固別 の果害中の糖含量とアスコルビン酸含量について調查し ているが，日照条件の良い外側の果実ほど煻含量やアス コルビン酸含量の高いことを報告した．本報告の遮光処 理によって明らかに煻含量が減少し，対照区に比べフル クトース含量は $81.8 \%$ ，スクロース含量は $64.5 \%$ であ った（Table 1).また袋掛け処理区でも，これらの含 量は若干滅少した。糖含量の減少は，摘葉処理，過着果 処理によっても顕著であったが，いずれの処理において も，スクロース含量の低下が著しかった（Table 3).

リンゴ樹の光合成産物の転流物質はソルビトールが主 であるが，果実中でンルビトールはスクロース，フルク トース，グルコースに転換される9．また，リンゴ果実 の糖含量は，発育当初はフルクトース、グルコース，ス クロースの順に多く含有されているが，成熟期に入る之 スクロースが増加し始め，グルコース含量を上回る ${ }^{10)}$. このことに関して，温州ミカンでは枝中の転流物質は通 常スクロースを主体とするが，幼果期から果実肥大期， 果実肥大期加成熟期にかけての転換期には，転流物質 
Table 1 Effect of light condition on sugar and malic

\begin{tabular}{|c|c|c|c|c|}
\hline Treatment & $\begin{array}{l}\text { Fruit weight } \\
\text { (g) }\end{array}$ & $\begin{array}{l}\text { Firmness } \\
(\mathrm{lb})\end{array}$ & Coloring $^{2}$ & $\begin{array}{c}\text { Malic acid } \\
\left(\mathrm{g} \cdot 100 \mathrm{ml} l^{-1}\right)\end{array}$ \\
\hline Shading & $219.0^{\mathrm{gy}}$ & $10.1^{\mathrm{a}}$ & 2. $0^{\mathrm{a}}$ & $0.334^{\mathrm{a}}$ \\
\hline Bagging $(\mathrm{A})^{\mathrm{x}}$ & $255.8^{\mathrm{ab}}$ & $12.9^{\mathrm{b}}$ & $4.3^{\mathrm{b}}$ & $0.358^{\mathrm{a}}$ \\
\hline Bagging (B) ${ }^{w}$ & $247.8^{\mathrm{ab}}$ & $12.5^{\mathrm{b}}$ & $1.0^{\mathrm{a}}$ & $0.417^{\mathrm{a}}$ \\
\hline Control & $266.4^{\mathrm{b}}$ & $13.2^{\mathrm{b}}$ & $5.2^{\mathrm{b}}$ & $0.342^{\mathrm{a}}$ \\
\hline Colored portion & - & $12.0^{\vee}$ & 5.4 & 0.374 \\
\hline Uncolored portion & - & 10.8 & 1.8 & 0.380 \\
\hline Significance & & NS & $* *$ & NS \\
\hline
\end{tabular}

${ }^{2}$ Coloring was judged by color chart for 'Fuji' apple fruit (Smaller number shows inferior

${ }^{y}$ Data shown are the means of 10 fruits from each of three branch replicates.

Different letters within column represent significant differences according to Duncan's multiple

${ }^{x}$ Bag was removed on 15 days before harvesting.

" Bag was not removed during fruit development.

"Data shown are the means of 20 fruits.

Significant at $5 \%$ level $(*)$ and $1 \%$ level (**)

Table 2 Effect of light condition on ascorbic acid content in a pulp and peel of 'Senshu' apple fruit

\begin{tabular}{|c|c|c|c|c|c|c|}
\hline \multirow{2}{*}{ Treatment } & \multicolumn{3}{|c|}{ Pulp (mg. $100 \mathrm{~g} \mathrm{f.w.}^{-1}$ ) } & \multicolumn{3}{|c|}{ Peel (mg $\left.\cdot 100 \mathrm{~g} \mathrm{f.w} .^{-1}\right)$} \\
\hline & AsA & DAsA & Total & AsA & DAsA & Total \\
\hline Shading & $0.3^{\mathrm{az}}$ & $0.3^{a}$ & $0.6^{\mathrm{a}}$ & $8.8^{\mathrm{a}}$ & $2.9^{a b}$ & $11.7^{\mathrm{a}}$ \\
\hline Bagging (A) ${ }^{y}$ & $2.2^{\mathrm{b}}$ & $0.9^{\mathrm{ab}}$ & 3. $1^{\mathrm{bc}}$ & $20.9^{\mathrm{b}}$ & 3. $9^{b}$ & $24.8^{\mathrm{b}}$ \\
\hline Bagging $(B)^{x}$ & $0.9^{\mathrm{ab}}$ & $0.4^{\mathrm{ab}}$ & $1.3^{\mathrm{ab}}$ & $4.5^{\mathrm{a}}$ & $1.8^{\mathrm{a}}$ & $6.3^{\mathrm{n}}$ \\
\hline Control & $2.5^{\mathrm{b}}$ & $1.3^{b}$ & $3.8^{\mathrm{c}}$ & $36.3^{\mathrm{c}}$ & $10.2^{\mathrm{c}}$ & $46.5^{\mathrm{c}}$ \\
\hline Colored portion & 1. $3^{w}$ & 1.1 & 2.4 & 39.3 & 1.1 & 40.4 \\
\hline Uncolored portion & 0.5 & 1.0 & 1.5 & 6.4 & 2.4 & 8.8 \\
\hline Significance & * & NS & NS & $* *$ & NS & $* *$ \\
\hline
\end{tabular}

${ }^{2}$ Data shown are the means of 10 fruits from each of three branch replicates.

Different letters within column represent signficant differences according to Duncan's multiple range test, $5 \%$ level.

${ }^{y}$ Bag was removed on 15 days before harvesting.

${ }^{x}$ Bag was not removed during fruit development.

"Data shown are the means of 20 fruits.

AsA : Ascorbic acid DAsA : Dehydroascorbic acid

がグルコースとフルクトースの混合物主体に変動するこ とあ報告されている゙1)，したがって，リンゴ果実中での 各種楉含量の增娍については，各時期における転流物質 との関連からも，今後検討していくことが必要であろ 5 .

本試験の遮光・摘葉・過着果処理区では，これらの報
告から，成熟期に葉からの光合成産物の供給が果実に十 分に行われなかったため，成熟期に増加してくるスクロ ースの増加が抑制されたものと推察される.

果実に袋掛けを行うことによって，果実中の糖含量の 減少することは以前にも報告されているが文，本報告の 袋掛け処理区でフルクトース，スクロース，全糖含量が 
acid content of 'Senshu' apple fruit

\begin{tabular}{|c|c|c|c|c|c|}
\hline \multicolumn{5}{|c|}{ Sugar content $\left(\mathrm{g} \cdot 100 \mathrm{~m} l^{-1}\right)$} & \multirow{2}{*}{$\begin{array}{l}\text { Sugar-Acid } \\
\text { ratio }\end{array}$} \\
\hline Glucose & Fructose & Sucrose & Sorbitol & Total & \\
\hline 1. $44^{\mathrm{a}}$ & $4.89^{\mathrm{a}}$ & $2.25^{\mathrm{a}}$ & $0.26^{\mathrm{b}}$ & $8.84^{\mathrm{a}}$ & $26.5^{\mathbf{a}}$ \\
\hline 1. $90^{\mathrm{b}}$ & $5.73^{\mathrm{c}}$ & $2.66^{\mathrm{ab}}$ & $0.18^{\mathrm{a}}$ & $10.47^{\mathrm{b}}$ & $29.2^{\mathrm{ab}}$ \\
\hline $1.41^{\mathrm{a}}$ & $5.43^{\mathrm{b}}$ & $3.08^{\mathrm{bc}}$ & $0.20^{\mathrm{ab}}$ & $10.12^{\mathrm{b}}$ & $24.3^{\mathrm{a}}$ \\
\hline $1.82^{\mathrm{b}}$ & $5.98^{\mathrm{d}}$ & $3.49^{c}$ & $0.27^{\mathbf{b}}$ & $11.56^{c}$ & $33.8^{\mathrm{b}}$ \\
\hline 1.81 & 6.59 & 4.14 & 0.33 & 12.87 & 34.4 \\
\hline 1.43 & 5.67 & 3. 77 & 0.27 & 11.14 & 29.3 \\
\hline NS & NS & NS & NS & NS & NS \\
\hline
\end{tabular}

coloring).

range test, $5 \%$ level.

減少したこと（Table 1)，さらに過着果処理の中でも， 着色の良い果実ほどフルクトース，スクロース含量值の 高かったこと（Table 3）は，果実における光合成も糖 含量に影響したものと推察された。

リンゴ果実のアスコルビン酸含量に関しての報告は, 主に光環境についての報告が多く，果実への袋掛けによ ってアスコルビン酸含量の減少することが報告されてい る”. 本報告でも同様な結果を得，遮光等の処理で大き 〈減少し，また同一果実内です着色部位でアスコルビン 酸含量の多かったこと（Table 2) は，アスコルビン酸 含量は光環境之密接に関連すると考えられる．しかしな がら，着色は優れてす摘葉処理によってアスコルビン酸 含量が大きく減少したこと（Table 4）は，光条件のみ ならず葉の光合成とも大きく関連性を持っていることを 示惨する，一方，“千秋’果実は果梗部に裂果の多い品 種であるが，裂果果実でアスコルビン酸含量が減少した こと（Table 6）は，硬度及びリンゴ酸含量值の低下 (Table 5)，あるいは詝蔵果実でアスコルビン酸が低下 しだという報告などから，傷害 (裂果) により果実か らのエチレン発生が旺盛となり ${ }^{22}$ ，果実の老化が促進さ れたためと考えられた。

Fig. 1 に示されるように, 糖含量, とくにフルクト 一ス及びスクロースと還元型アスコルビン酸との間に は，それぞれ $\mathrm{r}=0.554 ， \mathrm{r}=0.589$ の有意な正の相関が
得られた．糖含量とアスコルビン酸との密接な関連につ (ては，カンキッ13)，野菜類(4) であ報告されている。こ のことはリンゴ果実の還元型アスコルビン酸は糖から生

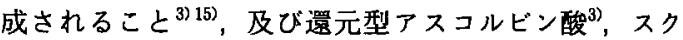
ロース ${ }^{10)}$ ともそれぞれ成熟期に急速に増加してくるこ とと関連性を持っているものと推察される，したがって， 果実中の糖ならびにアスコルビン酸含量の増加には良好 な光環境，葉の活発な光合成が必要と考えられる．さら に Table 1，3 の結果加ら糖含量の堌加には光合成産物 が，またTable 2，4 の結果から，アスコルビン酸含量 の增加には光条件がより大きな要因になっているものと 推察される.

果汁の品質を評価する際に，糖酸比も一つの指標とさ れる ${ }^{16)}$ ，遮光処理，果実人の袋斯け処理，過着果処理に よって糖酸比は明らかに低下したが，これらの処理下で も着色の良好な果実ほどその值が高くなり，対照区によ り近い値となった（Table 1，3），加工用果実の栽培体 系としては，できるだけ労力をかけないことが原則であ るが，摘花剂，摘果郕の使用により隔年結果を引き起こ さない着果量とすることは可能である ${ }^{5}$. このことに加 え，より高品質果汁の生産にあたっては，本試験の結果 から，特に成熟期に果実への光環境を良好にしてやるこ とも重要と考えられた。 
Table 3 Effects of defoliation and overcropping on sugar and

\begin{tabular}{|c|c|c|c|c|}
\hline Treatment & $\begin{array}{l}\text { Fruit weight } \\
\text { (g) }\end{array}$ & $\begin{array}{l}\text { Firmness } \\
\text { (lb) }\end{array}$ & Coloring ${ }^{2}$ & $\begin{array}{l}\text { Malic acid } \\
\left(\mathrm{g} \cdot 100 \mathrm{~m} l^{-1}\right)\end{array}$ \\
\hline Defoliation & $239.5^{y}$ & 11.8 & 4.2 & 0.346 \\
\hline Control & 245.0 & 12.4 & 4.0 & 0.436 \\
\hline Significance & NS & NS & NS & NS \\
\hline Overcropping $(A)^{x}$ & $190.2^{\mathrm{av}}$ & $12.1^{\mathrm{a}}$ & $3.4^{b}$ & $0.305^{\mathrm{a}}$ \\
\hline Overcropping (B) ${ }^{\text {w }}$ & $161.3^{\mathrm{a}}$ & $12.5^{\mathrm{a}}$ & 1. $0^{\mathrm{a}}$ & $0.331^{\mathrm{a}}$ \\
\hline Control & $266.4^{\mathrm{b}}$ & 13. $2^{\mathrm{g}}$ & 5. $2^{\mathrm{c}}$ & $0.342^{\mathbf{a}}$ \\
\hline
\end{tabular}

The same as in Table 1.

${ }^{y}$ Data shown are the means of 10 fruits from each of three branch replicates.

${ }^{x}$ Fruit whose coloring is superior.

"Fruit whose coloring is inferior.

"Data shown are the means of 10 fruits from each of three tree replicates. Different letters within

Table 4 Effects of defoliation and overcropping on ascorbic acid content in a pulp and peel of 'Senshu' apple fruit

\begin{tabular}{|c|c|c|c|c|c|c|}
\hline \multirow{2}{*}{ Treatment } & \multicolumn{3}{|c|}{ Pulp (mg $\left.\cdot 100 \mathrm{~g} \mathrm{f.w} .^{-1}\right)$} & \multicolumn{3}{|c|}{ Peel (mg $\left.\cdot 100 \mathrm{~g} \mathrm{f.w.}^{-1}\right)$} \\
\hline & AsA & DAsA & Total & AsA & DAsA & Total \\
\hline Defoliation & $0.9^{2}$ & 0.5 & 1.4 & 22.7 & 5.9 & 28.6 \\
\hline Control & 2.3 & 1.2 & 3.5 & 33.7 & 7.1 & 40.8 \\
\hline Significance & * & ${ }^{*}$ & $* *$ & $*$ & NS & $*$ \\
\hline Overcropping $(A)^{y}$ & $1.1^{\mathrm{aw}}$ & $1.1^{\mathrm{a}}$ & 2. $2^{\mathrm{a}}$ & $27.0^{\mathrm{ab}}$ & 8. $1^{\mathrm{ab}}$ & $35.1^{\mathrm{ab}}$ \\
\hline Overcropping (B) ${ }^{x}$ & $1.1^{\mathrm{a}}$ & $1.1^{\mathrm{a}}$ & 2. $2^{\mathrm{a}}$ & $20.6^{\mathrm{a}}$ & $4.0^{\mathrm{a}}$ & $24.6^{\mathrm{B}}$ \\
\hline Control & $2.5^{\mathrm{b}}$ & $1.3^{\mathrm{a}}$ & 3. $8^{\mathrm{b}}$ & $36.3^{b}$ & $10.2^{\mathrm{b}}$ & $46.5^{b}$ \\
\hline
\end{tabular}

${ }^{2}$ Data shown are the means of 10 fruits from each of three branch replicates.

${ }^{y}$ Fruit whose coloring is superior.

${ }^{x}$ Fruit whose coloring is inferior.

" Data shown are the means of 10 fruits from each of three tree replicates.

Different letters within column represent signficant differences according to Duncan's multiple range test, $5 \%$ level.

Table 5 Effect of cracking on sugar and malic acid

\begin{tabular}{|c|c|c|c|c|}
\hline Treatment & $\begin{array}{l}\text { Fruit weight } \\
\text { (g) }\end{array}$ & $\begin{array}{l}\text { Firmness } \\
(\mathrm{lb})\end{array}$ & Coloring ${ }^{z}$ & $\begin{array}{l}\text { Malic acid } \\
\left(\mathrm{g} \cdot 100 \mathrm{~m} l^{-1}\right)\end{array}$ \\
\hline Cracking & 179.5 & 12.2 & 5.0 & 0.315 \\
\hline Control & 177.3 & 13.3 & 5.4 & 0.413 \\
\hline Significance & NS & * & NS & * \\
\hline
\end{tabular}

${ }^{2}$ The same as in Table 1 .

Data shown are the means of 20 fruits. 
malic acid content of 'Senshu' apple fruit

\begin{tabular}{cccccc}
\hline \hline \multicolumn{5}{c}{ Sugar content $\left(\mathrm{g} \cdot 100 \mathrm{ml}^{-1}\right)$} & \multirow{2}{*}{$\begin{array}{c}\text { Sugar-Acid } \\
\text { ratio }\end{array}$} \\
\hline Glucose & Fructose & Sucrose & Sorbitol & Total & \\
\hline 1.60 & 5.06 & 1.71 & 0.15 & 8.52 & 24.6 \\
1.44 & 5.54 & 3.43 & 0.26 & 10.67 & 24.5 \\
\hdashline NS & $*$ & $* *$ & NS & ${ }^{*}$ & NS \\
\hline $1.53^{\mathrm{a}}$ & $4.95^{\mathrm{b}}$ & $2.25^{\mathrm{b}}$ & $0.15^{\mathrm{a}}$ & $8.88^{\mathrm{b}}$ & $29.1^{\mathrm{ab}}$ \\
$1.41^{\mathrm{a}}$ & $4.25^{\mathrm{a}}$ & $1.24^{\mathrm{a}}$ & $0.40^{\mathrm{a}}$ & $7.30^{\mathrm{a}}$ & $22.1^{\mathrm{a}}$ \\
$1.82^{\mathrm{a}}$ & $5.98^{\mathrm{c}}$ & $3.49^{\mathrm{c}}$ & $0.27^{\mathrm{a}}$ & $11.56^{\mathrm{c}}$ & $33.8^{\mathrm{b}}$ \\
\hline
\end{tabular}

column represent significant differences according to Duncan's multiple range test, $5 \%$ level.
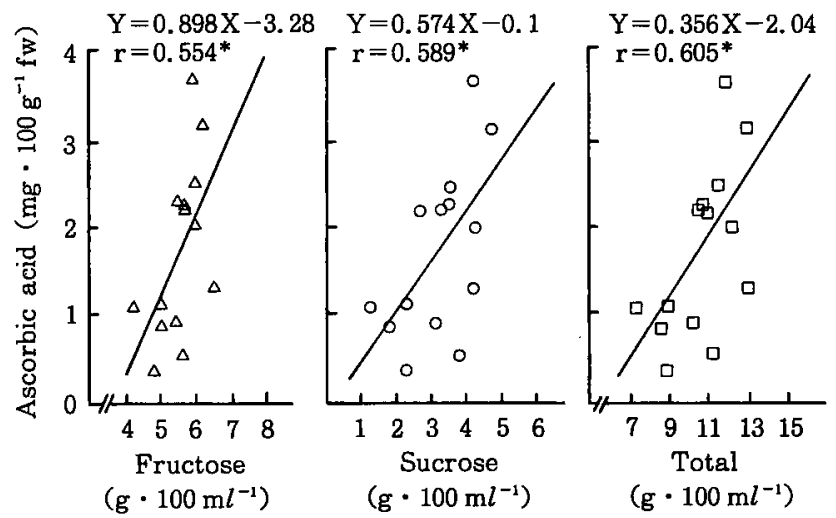

Fig. 1 Relationship between fructose, sucrose and total sugar, and ascorbic acid content in a pulp of 'Senshu' apple fruit Significant at $5 \%$ level $\left(^{*}\right)$

content of 'Senshu' apple fruit

\begin{tabular}{|c|c|c|c|c|c|}
\hline \multicolumn{5}{|c|}{ Sugar content $\left(\mathrm{g} \cdot 100 \mathrm{~m} l^{-1}\right)$} & \multirow{2}{*}{$\begin{array}{l}\text { Sugar-Acio } \\
\text { ratio }\end{array}$} \\
\hline Glucose & Fructose & Sucrose & Sorbitol & Total & \\
\hline 1.47 & 5.69 & 3.29 & 0.31 & 10.76 & 34.2 \\
\hline 1.54 & 5.96 & 4.15 & 0.31 & 11.96 & 29.0 \\
\hline NS & NS & $*$ & NS & NS & NS \\
\hline
\end{tabular}


Table 6 Effect of cracking on ascorbic acid content in a pulp and peel of 'Senshu' apple fruit

\begin{tabular}{|c|c|c|c|c|c|c|}
\hline \multirow{2}{*}{ Treatment } & \multicolumn{3}{|c|}{ Pulp (mg $\left.\cdot 100 \mathrm{~g} \mathrm{f.w.}^{-1}\right)$} & \multicolumn{3}{|c|}{ Peel (mg $\left.\cdot 100 \mathrm{~g} \mathrm{f.w} .^{-1}\right)$} \\
\hline & AsA & DAsA & Total & AsA & DAsA & Total \\
\hline Cracking & 2.3 & 0.4 & 2.7 & 32.6 & 5.2 & 37.8 \\
\hline Control & 3.7 & 0.8 & 4.5 & 53.5 & 5.8 & 59.3 \\
\hline Significance & * & NS & * & * & NS & $*$ \\
\hline
\end{tabular}

Data shown are the means of 20 fruits.

要約

果汁品質が良好であるリンゴ ‘千秋’果実について, 光環境，着果量など環境条件と各種糖含量，アスコルビ ン酸含量との関係について検討した。

1. 遮光処理，果実への袋掛け処理とも，対照区に比 ベグルコース，フルクトース，スクロース含量が滅少し た。特にスクロース含量は，遮光処理区で咸少が著しか った。また，アスコルビン酸含量す遮光，袋掛け処理に よって減少した。

2. 摘葉処理区では全糖含量が大きく減少し，とりわ けスクロースの減少が著しかった．またアスコルビン酸 含量も滅少した。

過着果処理では対照区に比べ，フルクトース，スクロ 一ス含量は大きく減少し，アスコルビン酸含量む隇少し た ただし着色の良好な果実では着色の劣る果実に比べ, これらの値はいずれも高かった。

以上から，リンゴ果実の糖含量の中でも，スクロース 含量が光条件や着果量によって大きく影響を受け，また アスコルビン酸含量は光条件に加え, 葉の㗢きとも密接 に関係することが示唆された。

本試験を行うに当たり，アスコルビン酸の分析に関し て御指導いただいた農林水産省果樹試験場，垣内典夫博 士に，また有益な御助言をきただいた当試験場，鈴木栄 司栽培部長に感謝いたします。
文献

1）苫名 孝: 果実の生理 (養賢堂, 東京), p. 57 (1971).

2）近藤 悟 - 水野 昇・高橋佑治: 秋田果樹試報， 18, 23 (1987).

3）丙山誠一・原田順厚・岡本辰夫：弘前大学報, 21 , 82 (1973).

4）葛西文造：東北女子短期大学紀要，17，48 (1978).

5）近藤 悟 - 鈴木栄司: 東北農業研究，44，199 (1991).

6) Masuda, R., Hayakawa, A., Kakiuchi, N. and Iwamoto, M. : Rep. Natl. Food Res. Inst, 52, 30 (1988).

7) Richard, C.R. and NaHrwold, D.L.: Anal, Biochem., 114, 140 (1981).

8）泉 秀実 - 伊藤卓桠 - 吉田保治 : 園学雑, 58, 877 (1990)

9) Hansen, P. : Physiol. Plant., 23, 564 (1970).

10) Kondo, S., Uthaibutra, J. and Gemma, H. : J. Japan. Soc. Hort. Sci., 60, 505 (1991).

11）沢村正義・中島正利・筬島 豊: 農化，49，603 (1975).

12) Abeles, F.B.: Ethylene in plant biology, (Academic Press, New York), p. 87 (1973).

13）泉 秀実・伊藤卓桠・吉田保治 : 園学雑, 57, 304 (1988).

14）篠原 温 - 田中邦雄・鈴木芳夫・山崎肯哉：園学 雑, 47, 63 (1978)

15) Loewus, F : Ann. Rev. Plant. Physiol., 22, 337 (1971).

16）日本果汁協会：果汁・果実飲料事典，稲垣長典 三浦 洋・小曾戸和夫・幸野憲二・服部達彦編 (朝倉書店, 東京), p. 204（1981）.

(平成 4 年 6 月 17 日受理) 